\title{
Combined learning, a good solution for Vietnamese universities
}

\author{
Pham Thi Thu Hoa ${ }^{1 *}$ \\ ${ }^{1}$ An Giang University, Vietnam \\ *Corresponding author: ptthoa@agu.edu.vn
}

\begin{tabular}{|c|c|}
\hline ARTICLE INFO & ABSTRACT \\
\hline $\begin{array}{l}\text { DOI:10.46223/HCMCOUJS.so } \\
\text { ci.en.9.1.273.2019 }\end{array}$ & $\begin{array}{l}\text { Information technology has created tremendous chances in } \\
\text { higher education across the globe. With the availability and } \\
\text { flexibility of learning online, there are increasing competitions } \\
\text { between online learning and traditional, face-to-face classroom. } \\
\text { These two types of learning both have their pros and cons. From }\end{array}$ \\
\hline Received: April 9 $9^{\text {th }}, 2019$ & the advantages and disadvantages of online learning, universities \\
\hline Revised: July $6^{\text {th }}, 2019$ & have recently changed the way of their teaching by combining \\
\hline Accepted: July $17^{\text {th }}, 2019$ & $\begin{array}{l}\text { online learning and traditional classroom. Therefore, it is } \\
\text { necessary to investigate and understand the advancements of the } \\
\text { combination of the two types of learning. In this paper, we will } \\
\text { introduce the advantages and disadvantages of online learning and } \\
\text { combined learning. We also share our experience of teaching at }\end{array}$ \\
\hline $\begin{array}{l}\text { Keywords: } \\
\text { combined learning, online } \\
\text { learning in Vietnam, online } \\
\text { learning, traditional learning }\end{array}$ & $\begin{array}{l}\text { Flinders University, South Australia through Flinders learning } \\
\text { online system. From this knowledge, we will suggest some } \\
\text { solutions for building a combined learning system which is } \\
\text { suitable for Vietnamese universities. }\end{array}$ \\
\hline
\end{tabular}

\section{Introduction}

Information technology has changed the nature of education and the jobs of educators. Online education is electronically supported learning that relies on the internet for teachers and students interaction and the distribution of class materials (Hoic-Bozic, Dlab, \& Mornar, 2016; Van der Zee, Admiraal, Paas, Saab, \& Giesbers, 2017). Online education has rapidly become a highly popular method of education. There are thousands of online courses which provide global and free access to high quality education. With a reliable internet connection, students can gain access to a large variety of massive open online courses (MOOCs) found on platforms such as Coursera and edX.

MOOC participants indeed come from all over the world. Language barrier is really a visible problem for non-native English students. Therefore, to ensure not only the availability but also the accessibility of open online education, courses are designed to minimize the negative effects of a language barrier. In case that there are many non-native English speakers in English courses, the courses are provided with not only English subtitles but also their national language (Van der Zee et al., 2017).

Online learning includes all forms of electronic learning and teaching support (Le \& Truong, 2011; Vu, 2015). Online communication serves as a specific means of communication to implement the learning process. This term is used to talk about studying in the classroom or 
outside the classroom through technology. In an online learning community, people share knowledge through written discussion, audio, video, or other Internet supports. This creates an environment with opportunities for personal opinion presentation.

The modern world of education experiences competition between the two styles of learning: traditional learning and online learning (Hoic-Bozic et al., 2016; Le \& Truong, 2011; $\mathrm{Vu}, 2015)$. Therefore, universities have recently changed the way of their teaching by combining online learning and traditional classroom. Combined learning, hybrid education or blended learning, allows students to pursue a combination of online and classroom courses. This type of learning attempts to put together the benefits of studying in a traditional learning environment with the convenience that distance learning and online learning provider. Part of the course or programme is studied on the students' own time and from home, and other parts of the course require attendance in the classroom. Which parts vary from course to course and some programmes are even being offered in a sort of dual learning format whereby a student can swap from learning on campus to learning at home from week to week, depending on commitments and whatever suits their schedule best.

Combined learning is described as a combination of face-to-face and online learning (Hoic-Bozic et al., 2016; Vu, 2015). In combined learning, students studying on-campus and off-campus are provided with distance education materials such as online learning resources and team project sites. Students have only tutorial contact in person with their lecturer or academic staff. Combined learning has been promoted as a high-quality instructional method for over 40 years, and it has been often found more effective than strictly face-to-face or strictly online instruction.

In recognition of the important role of education and training, particularly active learning in higher education in contributing to the quality of the future workforce and the modernization of Vietnam, the communist party and the government have considered education and training, and science and technology as areas of national priority (MOET, 2015; Vu, 2015). Teaching and learning methods have been reformed to encourage students' active engagement or to make students become more active and involved in their learning process. The MOET launched the year of information and communication technology in education in the school year 2008-2009 to promote the use of information and communication technology in innovative teaching and learning methods.

Based on the different types of learning, the comparison among traditional learning, online learning and combined learning models is presented in Table 1.

\section{Table 1}

Comparison among traditional learning, online learning and combined learning

\begin{tabular}{|c|l|l|l|}
\hline & Traditional learning & \multicolumn{1}{|c|}{ Online learning } & Combined learning \\
\hline Announcement & $\begin{array}{l}\text { Flyer } \\
\text { Mail } \\
\text { Phone }\end{array}$ & $\begin{array}{l}\text { LOS (learning online } \\
\text { system) } \\
\text { Email }\end{array}$ & $\begin{array}{l}\text { LOS } \\
\text { Email }\end{array}$ \\
\hline Overview session & Traditional classroom & LOS & $\begin{array}{l}\text { LOS } \\
\text { Traditional } \\
\text { classroom }\end{array}$ \\
\hline Self-paced & Books & E-books & E-books \\
\hline
\end{tabular}




\begin{tabular}{|c|l|l|l|}
\hline learning & Traditional learning & \multicolumn{1}{|c|}{ Online learning } & Combined learning \\
\hline Query resolution & Articles & $\begin{array}{l}\text { Web-based tutorial } \\
\text { Recorded lectures } \\
\text { Videos }\end{array}$ & $\begin{array}{l}\text { Books } \\
\text { Web-based tutorial } \\
\text { Recorded lectures } \\
\text { Videos }\end{array}$ \\
\hline $\begin{array}{c}\text { Demonstration } \\
\text { and practice }\end{array}$ & $\begin{array}{l}\text { Traditional classroom } \\
\text { Workbook } \\
\text { assignments } \\
\text { Study group }\end{array}$ & $\begin{array}{l}\text { Email } \\
\text { Frequently asked } \\
\text { question (FAQ) } \\
\text { Instant messenger } \\
\text { Online mentors }\end{array}$ & $\begin{array}{l}\text { Web meeting } \\
\text { Frequently asked } \\
\text { question (FAQ) } \\
\text { Instant messenger } \\
\text { Online mentors } \\
\text { Face to face meeting }\end{array}$ \\
\hline $\begin{array}{c}\text { Discussion forums } \\
\text { examination }\end{array}$ & $\begin{array}{l}\text { Traditional } \\
\text { classroom } \\
\text { Workbook } \\
\text { assignments } \\
\text { Study group } \\
\text { Web meeting }\end{array}$ \\
& Traditional classroom & $\begin{array}{l}\text { Online assignments } \\
\text { and quizzes } \\
\text { Online test }\end{array}$ & $\begin{array}{l}\text { Traditional } \\
\text { classroom } \\
\text { Online assignments } \\
\text { and quizzes }\end{array}$ \\
\hline Feedback & Face to face meeting & Email & $\begin{array}{l}\text { Email } \\
\text { Face to face meeting }\end{array}$ \\
\hline
\end{tabular}

Source: The researcher's data analysis

I have focused mainly on the advantages and disadvantages of online learning and combined learning. This paper is structured as follows: Section 2 introduces the advantages and disadvantages of learning online followed by the advantages of combined Learning in Section 3. In Section 4, we will share our experiences in teaching at Flinders University through Flinders learning online system. Basing on this experience, I will give some suggestions and conclusions about building a combined learning system for Vietnamese universities.

\section{The advantages and disadvantages of online learning}

The development of multimedia and information technologies, as well as the use of Internet has made significant changes in the traditional process of learning. Online learning has become more and more popular in institutions of higher education (Arkorful \& Abaidoo, 2015; Le \& Truong, 2011; Powell et al., 2015; Stephen, 2005; Van der Zee et al., 2017; Vu, 2015). These are some advantages and possible disadvantages of online learning in education obtained from Arkorful and Abaidoo (2015) (Table 2).

\section{Table 2}

Advantages and possible disadvantages of online learning

\begin{tabular}{|c|c|c|}
\hline & Advantages & Possible disadvantages may cause \\
\hline Time and place & $\begin{array}{l}\text { Completely flexible to choose } \\
\text { an effective time and a place } \\
\text { to study }\end{array}$ & $\begin{array}{l}\text { May lack of face-to-face interaction } \\
\text { or relation } \\
\text { May requires a very strong }\end{array}$ \\
\hline
\end{tabular}




\begin{tabular}{|c|l|l|}
\hline & \multicolumn{1}{|c|}{ Advantages } & Possible disadvantages may cause \\
\hline Teaching materials & $\begin{array}{l}\text { Supportive discussion forums } \\
\text { Huge number of qualified } \\
\text { sources and materials on the } \\
\text { internet }\end{array}$ & $\begin{array}{l}\text { motivation and time management } \\
\text { skills }\end{array}$ \\
\hline Cost & $\begin{array}{l}\text { No need to travel lead to congestion or } \\
\text { ho need to have classroom } \\
\text { No limit of the size of class }\end{array}$ & $\begin{array}{l}\text { May affect the fairness of tests and } \\
\text { assessments in online learning }\end{array}$ \\
\hline Self-paced learning & $\begin{array}{l}\text { Allow each student to study } \\
\text { at their own pace } \\
\text { Focus on the individual } \\
\text { learner differences }\end{array}$ & May impact socialization skills \\
\hline Academic staff & $\begin{array}{l}\text { Reduce the number of } \\
\text { academic staffs }\end{array}$ & May limit the role of instructors \\
\hline
\end{tabular}

Source: The researcher's data analysis

First, choosing the time and place for studying in online learning is very flexible. This type of learning can provide much flexibility for the institutions to deliver learning information as well as for their students or learners to receive the information (Arkorful \& Abaidoo, 2015; Stephen, 2005). Every student has many ways of choosing the place and time that suits them. However, with the way of learning in a far distance, students may lack face-to-face interaction or relation. It, therefore, requires very strong motivation and time management skills from students and support from the administrators to reduce such effects.

In other to provide opportunities for relations between learners and teachers, online learning uses discussion forums. Through this, online learning helps eliminate barriers that may affect activities such as demonstration, giving feedback and querying resolution. Online learning motivates students to interact with others and overcome the fear of talking to other learners, as well as exchange and respect different points of view during content delivery (Powell et al., 2015; Stephen, 2005).

Another advantage of online learning is that it can exploit a huge number of qualified sources and materials on the internet. Online learning enhances the efficacy of knowledge and qualifications via ease of access to teaching sources from prestigious universities and lecturers. However, with a huge amount of information, it also causes some disadvantages. It may also lead to congestion or heavy use of some websites. Moreover, learners need to spend more time and effort to clarify and understand the materials. With respect to clarifications, explanations, and interpretations, the online learning method may be less effective than traditional methods of learning. The learning process is sometimes much easier to have a face-to-face meeting with instructors or teachers.

Third, online learning is cost effective in the sense that there is no need for students or learners to travel. It also reduces the studying cost in the sense that it offers opportunities of learning for a maximum number of learners with no need for many buildings. On other hand, since tests and assessments in online learning are frequently supervised by staff or mentors, it may be difficult, if not impossible, to control or regulate activities such as cheating. Online 
learning may also be subject to piracy, plagiarism, cheating, inadequate selection skills, and inappropriate use of copy and paste.

Fourth, online learning always takes the individual learner differences into its consideration. Some learners prefer to concentrate on certain parts of the course or specific subjects, while others are prepared to review the entire course. In addition, this way of learning allows self-pacing. The nonparallel way of teaching in online learning permits each student to study at his or her own pace and speed whether slow or quick. It, therefore, increases satisfaction and decreases stress. However, when students need to improve their communication skills, online learning may have a negative effect. Though students might have excellent academic knowledge, they may not possess the necessary skills to deliver their acquired knowledge to others.

Finally, online learning can make good use of online lectures. Therefore, it can solve the lack of academic staff, including instructors or teachers as well as facilitators, lab technicians, etc. However, not all disciplines can effectively use online learning in education. Scientific fields that require hands-on practical experiences may be more difficult to study through online learning such as medical science and engineering than social science and humanities.

\section{The advantages of combined learning}

Although online learning has a lot of advantages compared to traditional learning, it also reveals many disadvantages. Online learning obviously could not completely replace the classroom experience and the advantage of face-to-face interaction with teachers and other students. Being able to talk to the tutor of a course offers an opportunity that can help learners understand difficult concepts. Besides, face to face meeting with other students can provide opportunities to find study partners and collaborators in learning. Nevertheless, using the tools of the internet is a valuable means to extend the reach of students' knowledge. The internet makes available to all students a wealth of information that no library of the past could have hoped to hold individually. Students still need guidance from teachers to find the information they need for their studies. By having the face-to-face interaction between teachers and students, it is easy to deliver and explain new knowledge (Arkorful \& Abaidoo, 2015; HoicBozic et al., 2016; Singh, 2003; Spanjers et al., 2015; Vu, 2015).

Combined learning is a natural development to the growing accessibility of online learning and the continued need for students in traditional learning. Combined learning is important because it breaks down the traditional ways of teaching. Moreover, this type of learning also places students at the center of the learning process, harnessing the power of technology to create more engaging, efficient, and success-oriented learning environments. It can take advantages and reduce a lot of disadvantages from both online learning and traditional learning. Following is the advantages of combined learning for students.

First, combined learning takes advantages of online learning which offers a flexible way of learning in terms of availability anytime, anywhere. In other words, this type of learning enables the student to access the materials and video lectures from anywhere, at any time. Second, students can gain knowledge through a variety of learning activities that apply to the two learning styles. 
They can also study at their own pace. Due to the flexibility of online learning and the ability to access internet resources, students can set appropriate learning goals and take charge of his or her own learning. In addition to this, teachers can help speed up students' learning process by giving more advanced resources or discussing if necessary, through combined learning.

Third, students can track their progress through an online learning system. Students become self-driven and responsible, tracking their individual achievements. This feeling of responsibility helps students to develop the ability to solve problems and seek help when they need. So, they can feel more confident in the process of reaching their goals. Combined learning also provides effective interactions between the learners and their instructors from both types of learning using mails, discussion boards, traditional classroom and chat room. Especially, combined learning supports face-to-face teaching approaches so that it could avoid the difficulties of online learning and could improve the quality of teaching and learning.

Finally, by using the online learning system, teachers can instantly diagnose information and review student feedback. With the ability to rapidly analyze, review and give feedback to student work, teachers can modify their teaching methods and feedback for each student while improving time efficiency.

\section{Suggestions and conclusions about building combined learning system for Vietnamese universities}

I had taught statistical topics such as biostatistics, statistical methods for engineering and science, data analysis laboratory and applied statistics laboratory at Flinders University from 2014 to 2016. In Flinders University, they have organized the combined learning through Flinders learning online.

Combined learning is a type of learning that combines traditional learning and online learning. This rotational model divides a student's learning into part traditional classroom instruction and part virtual learning. In this type of learning, courses are designed by coordinators differently depend on students' needs and each specific subject. This type of learning allows students to process and learn materials in a way that best suits them, and teachers are required to lay the foundation on which students learn. The teacher sets a schedule for the course and the students rotate through the instruction modules. Some classes might require classroom instruction or a lab, while other courses might be taught completely in a virtual environment. For courses that are completely virtual, there are some supporting activities taking place which will help students who might not have the self-discipline or needed support system to complete all their coursework.

I have also been a lecturer at An Giang University since 2002. I would like to give some suggestions about building a combined learning system for Vietnamese universities, especially for An Giang University.

We should build an effective learning online system (LOS). LOS will supply flexible and convenient ways of learning for students. In this system, we build a learning and teaching platform of online educational environments. In addition, LOS can be used to create entire online topics and courses. This system could also provide interactive tools that supplement or complement existing topics and courses. LOS has to be accessible to all staff and students. The 
main parts of LOS are a list of all topics that the user personally has access to, student information system, email and library account.

The staff and lectures in the University should be trained and have prepared for the combined learning. In particular, teaching teams have to design courses which satisfy students' choices including online learning, combined learning and traditional learning. Lectures need to modify their topics suitable for each learning type. They also need to be trained about using LOS for their teaching and engage students to interact with each other from the comfort of using LOS. Moreover, online learning services such as learning design service, online support service and professional development for technology enhanced learning need to be built to support teaching teams and university staff.

A topic on LOS consists of resources, activities and tools for managing to learn. Resources on LOS display topic content such as lecture notes, tutorial activities, recorded lectures and video files. Activities on LOS are a range of online activities that can support learning and teaching, such as assignment dropboxes, quizzes, surveys, discussion forums and feedback. Tools for managing learning on LOS such as the grade book can be used to record and monitor student progress.

Furthermore, universities in Viet Nam should cooperate with each other to provide qualified and advanced courses through combined learning. One of the universities produces an advanced course and broadcast the course with students in other universities via a conferencing system. The course is designed for a specialized subject under a prestigious lecturer and university. This way of learning can attract students by the quality of the courses and can promote cooperation among universities in Viet Nam.

\section{References}

Arkorful, V., \& Abaidoo, N. (2015). The role of e-learning, advantages and disadvantages of its adoption in higher education. International Journal of Instructional Technology and Distance Learning, 12(1), 29-42.

Hoic-Bozic, N., Dlab, M. H., \& Mornar, V. (2016). Recommender system and Web 2.0 tools to enhance a blended learning model. IEEE Transactions on education, 59(1), 39-44.

Le, N. T., \& Truong, H. A. (2011). Nghiên cưu đề xuất xây dụng mạng xã hội học tập tại Việt Nam [The study proposes to build a learning social network in Vietnam] (Master's thesis, University of Engineering and Technology, Hanoi, Vietnam).

MOET. (2005). Vietnam higher education renovation agenda - Period 2006-2020. Resolution No. 14/2005/NQ-CP on substantial and comprehensive renewal of vietnam's tertiary education in the 2006-2020 period. Retrieved March 19, 2019, from https://vanbanphapluat.co/resolution-no-14-2005-nq-cp-of-november-02-2005-onsubstantial-and-comprehensive-renewal-of-vietnam-s-tertiary-education-in-the-20062020-period

Powell, A., Watson, J., Staley, P., Patrick, S., Horn, M., Fetzer, L., ... Verma, S. (2015). Blending learning: The evolution of online and face-to-face education from 2008-2015. Promising practices in blended and online learning series. Retrieved March 10, 2019, from https://eric.ed.gov/?id=ED560788 
Singh, H. (2003). Building effective blended learning programs. Educational TechnologySaddle Brook Then Englewood Cliffs NJ-, 43(6), 51-54.

Spanjers, I. A., Könings, K. D., Leppink, J., Verstegen, D. M., de Jong, N., Czabanowska, K., \& van Merrienboer, J. J. (2015). The promised land of blended learning: Quizzes as a moderator. Educational Research Review, 15, 59-74.

Stephen, D. L. (2005). Responding to learner needs in distance education: Providing academic and relational support (PARS). In J. S. Levine (Ed.), Making distance education work: understanding learning and learners at a distance (pp. 73-87).

Van der Zee, T., Admiraal, W., Paas, F., Saab, N., \& Giesbers, B. (2017). Effects of subtitles, complexity, and language proficiency on learning from online education videos. Journal of Media Psychology Theories Methods and Applications, 29(1), 18-30.

Vu, H. X. (2015). Active learning in an ICT-enhanced blended learning environment: A case study of Vietnamese students in Australian higher education. (Unpublished doctoral dissertation). University of Wollongong, New South Wales, Australia. 